\title{
Utjecaj paleolitičke prehrane u trajanju od 12 tjedana na tjelesnu masu, HbA1c i kvalitetu života kod osoba oboljelih od dijabetesa tipa 2
}

\author{
Influence of 12 weeks of Paleolithic diet on body weight, HbAlc and quality of life in patients \\ with type 2 diabetes
}

\author{
Tihana Šadek $^{1 *}$, Ana Vukelić1, Manja Prašek² ${ }^{2}$ Zvonimir Šatalić1 \\ ${ }^{1}$ Prehrambeno-biotehnološki fakultet Sveučilišta u Zagrebu, Pierottijeva 6, 10000 Zagreb, Hrvatska \\ ${ }^{2}$ Zagrebačko dijabetičko društvo, Antuna Bauera 19, 10000 Zagreb, Hrvatska \\ *Corresponding author: tihanasadek@gmail.com
}

\section{Sažetak}

U današnje doba dijabetes tipa 2 jedno je od najčeščih kroničnih oboljenja kod kojeg se s vremenom, zbog loše metaboličke regulacije, razvijaju različite zdravstvene komplikacije. Osnovni princip liječenja dijabetesa tipa 2 je prehrana uz redovitu tjelesnu aktivnost, samokontrola i peroralna terapija prema uputi liječnika. Kako paleolitička prehrana ima karakteristike koje bi mogle biti od koristi u kontroli dijabetesa tipa 2, od nedavno se istražuje kao moguća prevencija i dijetoterapija. Cilj ovog rada bio je ispitati utjecaj paleolitičke prehrane na tjelesnu masu, indeks tjelesne mase kao i na parametar dugoročne glikemije (HbAlc) te procijeniti njenu prihvatljivost kod oboljelih $i$ utjecaj na kvalitetu života. Osam ispitanika s dijabetesom tipa 2 slijedilo je načela paleolitičke prehrane u trajanju od 12 tjedana. Nakon intervencije došlo je do vrlo malog smanjenja u tjelesnoj masi (1,4\%) i HbAlc $(0,1 \%)$ te se umjereno povećala kvaliteta života u pogledu društvenih odnosa (10,9\%) i utjecaja okoline (6,6\%). Paleolitička prehrana se pokazala prihvatljiva prema percepciji zdravstvenog utjecaja, lakoći pridržavanja, stupnju sitosti, ukusnosti, smanjenoj potrebi za slatkom hranom, lakoci nabave namirnica te prema percepciji općeg zdravlja $i$ blagostanja, dok je financijski trošak predstavljao jedini faktor neprihvatljivosti ovakvog načina prehrane.

Ključne riječi: dijabetes tipa 2, paleolitička prehrana, HbAlc, smanjenje tjelesne mase, kvaliteta života

\begin{abstract}
Today, type 2 diabetes is one of the most common chronic conditions in which various health complications develop over the time due to the poor metabolic regulation. The basic principle for the treatment of type 2 diabetes is nutrition with regular physical activity, self-check and prescribed medications. As the Paleolithic diet has characteristics that could be of use in control of type 2 diabetes, it has recently been explored as a possible prevention and diet therapy. The aim of this study was to examine the influence of the Paleolithic diet on body weight, body mass index as well as on the parameter of long-term glycemic control ( $\mathrm{HbAlc}$ ) and to assess its acceptability in patients and influence on quality of life. Eight participants with type 2 diabetes followed the Paleolithic diet for 12 weeks. After the intervention, there was a very small decrease in body weight (1.4\%) and HbAlc (0.1\%), and a moderate increase in quality of life in terms of social relations $(10.9 \%)$ and environmental impact (6.6\%). The Paleolithic diet has been proven acceptable according to the perception of health impact, ease of adherence, degree of satiety, overall taste, decreased desire to eat sugary foods, ease of purchasing food, and perception of general health and well-being, while financial cost was the only factor of the unacceptability of this diet.
\end{abstract}

Keywords: type 2 diabetes, Paleolithic diet, $H b A 1 c$, weight loss, quality of life

\section{Uvod}

Dijabetes tipa 2 u današnje je doba jedno od najčešćih kroničnih oboljenja te veliki zdravstveni izazov 21. stoljeća. Karakteriziran je visokom razinom glukoze u krvi (hiperglikemijom) zbog nedovoljnog izlučivanja inzulina ili zbog neučinkovite aktivnosti inzulina u mišićnom i masnom tkivu. S napredovanjem loše regulirane bolesti povećava se mogućnost nastanka kroničnih komplikacija. Zbog oštećenja krvnih žila i živaca, promjene se događaju na vitalnim organima cijelog tijela (srce, bubrezi, oči) što može dovesti do posljedica poput slijepila i amputacija, a nastale komplikacije predstavljaju veliki ekonomski trošak (Lieberman, 2003). Osim toga, osobe s dijabetesom tipa 2 izložene su većem riziku od kardiovaskularnih bolesti koje kod njih predstavljaju primarni uzrok smrti (Gregg i sur., 2012).

Procijenjeno je da danas u svijetu 463 milijuna osoba ima dijabetes, od čega je 90\% dijabetes tipa 2 . S obzirom na alarmantni porast incidencije obolijevanja, predviđa se da će do 2030. godine biti 578 milijuna oboljelih, a do 2045. godine čak 700 milijuna oboljelih od dijabetesa. Troškovi zdravstvene zaštite povezani s dijabetesom na svjetskoj su razini tijekom 2019. godine iznosili čak 760 milijardi dolara (IDF, 2019).

Prema podacima CroDiab Registra osoba sa šećernom bolešću, 2018. godine u Hrvatskoj je bilo oko 304000 osoba sa šećernom bolesti. No prema ranijim istraživanjima samo $60 \%$ ima postavljenu dijagnozu, što znači da bi se realan broj oboljelih mogao kretati i do 500 000. Dijabetes je posljedično 4. uzrok smrti s 4,4\% tijekom 2017. godine (HZJZ, 2019).

Ovo oboljenje smatra se posljedicom modernog načina života i prehrane. No, opaženo je da se takve bolesti nisu javljale kod lovaca-sakupljača iz doba paleolitika (u trajanju od prije 2,6 milijuna godina do prije deset tisuća godina) koji su se bavili lovom divljih životinja i sakupljanjem divljih vrsta biljaka (Jew i sur., 2009; Cordain i sur., 2005). Kako se prehrana ljudi iz paleolitika temeljila na unosu proteina i na niskom unosu ugljikohidrata niskog glikemijskog indeksa, takvu je prehranu pratila niska razina inzulina u krvi. Smatra se da je ljudski genom prilagođen na takav način prehrane i na niske razine inzulina (Kopp, 2006). Stoga se paleolitička prehrana počela proučavati kao potencijalni model koji bi mogao poslužiti za liječenje bolesti suvremenog doba poput dijabetesa tipa 2 (Lindeberg, 2012). 
Definicije paleolitičke prehrane prema izboru hrane koja je uključena i koja nije uključena navedene su u tablici 1 . Za prehranu poput ove, koju karakterizira povećan unos proteina, prehrambenih vlakana i omega-3 masnih kiselina te unos ugljikohidrata niskog glikemijskog indeksa, smatra se da doprinosi boljoj glikemijskoj kontroli, povećanju sitosti te smanjenju tjelesne mase kod pretilih osoba s dijabetesom tipa 2 (Jönsson i sur., 2010 ; Moosheer i sur., 2014).

Tablica 1. Različite definicije paleolitičke prehrane

Table 1. Different definitions of the Paleolithic diet

\begin{tabular}{|c|c|c|}
\hline Izvor & Hrana koja ulazi u sastav paleolitičke prehrane & Hrana koja ne ulazi u sastav paleolitičke prehrane \\
\hline Otten i sur., 2017 & $\begin{array}{c}\text { nemasno meso, jaja, riba, morski plodovi, voće i } \\
\text { povrće, orašasto voće }\end{array}$ & $\begin{array}{c}\text { mlijeko i mliječni proizvodi, žitarice, mahunarke, dodani } \\
\text { šećer i sol }\end{array}$ \\
\hline Boers i sur., 2014 & $\begin{array}{c}\text { nemasno meso, riba, jaja, voće, povrće (lisnato, } \\
\text { korjenasto i ono iz porodice krstašica), orašasto } \\
\text { voće }\end{array}$ & $\begin{array}{c}\text { mlijeko i mliječni proizvodi, žitarice, mahunarke, prerađene } \\
\text { masnoće, dodana sol i šećer }\end{array}$ \\
\hline Mellberg i sur., 2014 & $\begin{array}{c}\text { nemasno meso, riba, jaja, povrće, voće, bobice i } \\
\text { orašasto voće }\end{array}$ & $\begin{array}{c}\text { mlijeko i mliječni proizvodi, žitarice, dodana sol i šećer, } \\
\text { prerađene masnoće }\end{array}$ \\
\hline Masharani i sur., 2015. & $\begin{array}{c}\text { meso, riba, perad, jaja, voće, povrće, orašasto voće, } \\
\text { med }\end{array}$ & $\begin{array}{c}\text { mlijeko i mliječni proizvodi, mahunarke, žitarice, krumpir i } \\
\text { proizvodi s dodanom soli }\end{array}$ \\
\hline
\end{tabular}

Dvije dosad objavljene meta-analize obuhvatile su dosadašnje randomizirane kontrolirane studije o utjecaju paleolitičke prehrane. Meta-analiza Manheimer i sur. iz 2015. evidentirala je veći utjecaj paleolitičke prehrane na svih pet komponenti metaboličkog sindroma (najznačajnije na opseg struka, krvni tlak i razinu triglicerida), čak i u vrlo kratkom vremenskom periodu od dva tjedna, nego što su to imali kontrolni obrasci prehrane u pripadajućim istraživanjima. Druga meta-analiza obuhvatila je utjecaj paleolitičke prehrane na rizične čimbenike za nastanak kardiovaskularnih bolesti i zaključila kako paleolitička prehrana dovodi do smanjenja antropometrijskih parametara (tjelesna masa, indeks tjelesne mase, opseg struka, postotak masnog tkiva), krvnog tlaka, koncentracije CRP-a te do poboljšanja lipidnog profila (razina ukupnog, LDL i HDL kolesterola te razina triglicerida) (Ghaedi i sur., 2019). Ostala zabilježena poboljšanja koja bi mogla biti korisna kod dijabetičke populacije su bolja glikemijska kontrola i inzulinska osjetljivost te smanjena koncentracija inzulina i HbAlc u krvi. No s obzirom na nepostojanje studija dužeg trajanja i s većim brojem ispitanika, ne mogu se donijeti čvrsti zaključci o dugoročnom djelovanju ovakvog načina prehrane (Manheimer i sur., 2015).

Svrha istraživanja opisanog u ovom radu bila je ispitati kako paleolitička prehrana utječe na antropometrijske i biokemijske parametre, kao i na ukupno zadovoljstvo životom kod osoba s dijabetesom tipa 2 te je li prihvatljiva za pridržavanje.

\section{Ispitanici i metode}

\section{Ispitanici}

U suradnji sa Zagrebačkim dijabetičkim društvom (ZDD) u veljači 2019. godine održano je informativno predavanje kojim je paleolitička prehrana predstavljena članovima Društva (osobama s dijabetesom tipa 2) te je upućen poziv za sudjelovanje u istraživanju. Nakon prikupljanja potpisanih dobrovoljnih pristanaka, osam ispitanika (sedam žena i jedan muškarac) započelo je i završilo prehrambenu intervenciju. Ispitanici su prije uključivanja u istraživanje grupno informirani o prehrani i pravilima kojih se trebaju pridržavati te su upoznati s planom istraživanja.

\section{Dizajn istraživanja i metode}

Po uzoru na dosadašnja istraživanja definirano trajanje ovog istraživanja bilo je 12 tjedana, (od 1. ožujka do 31. svibnja 2019. godine). Ispitanicima je paleolitička prehrana predstavljena kao prehrana koja se temelji na nemasnom mesu, ribi, morskim plodovima, jajima, voću i povrću te orašastom voću, a koja isključuje žitarice i proizvode od žitarica, pekarske proizvode, mlijeko i mliječne proizvode, mahunarke, prerađenu hranu, gazirane napitke te dodani šećer i sol (tablica 1). Ispitanicima je podijeljen informativni letak s popisom namirnica koje se preporučuje odnosno ne preporučuje konzumirati (tablica 2. i 3.). Unos dozvoljene hrane nije bio ograničen niti su bile definirane proporcije kategorija hrane, kao ni energetski unos. Kako umjerene količine alkohola konzumirane uz obrok imaju minimalni akutni učinak na regulaciju glukoze u krvi, unos vina uz obrok je, za razliku od piva, bio dozvoljen te je najveći preporučeni dnevni unos predstavljao ekvivalent jedne čaše $(150 \mathrm{~mL})$ dnevno za žene i dvije čaše dnevno za muškarce (ADA, 2008). Uz sve navedeno, nije bilo definiranih zahtjeva povezanih s tjelesnom aktivnosti.

U tablici 2. navedene su vrste namirnica koje pripadaju paleolitičkoj prehrani, a u tablici 3. namirnice koje ne ulaze u sastav paleolitičke prehrane (Lindeberg i sur., 2007; Jönsson i sur., 2009; Boers i sur., 2014). 
Tablica 2. Hrana koja ulazi u sastav paleolitičke prehrane

Table 2. Food that belongs to the Paleolithic diet

\begin{tabular}{|c|c|}
\hline Skupina namirnica & Pripadajuća hrana \\
\hline Meso i riba & $\begin{array}{c}\text { Govedina, teletina, piletina, puretina, svinjetina, janjetina, meso patke, koze, divljači, iznutrice, meso i kobasice } \\
\text { bez nitrita i glutena, riba, morski plodovi, jaja }\end{array}$ \\
\hline Povrće & $\begin{array}{c}\text { Cikla, paprika, brokula, prokulice, kupus, mrkva, cvjetača, celer, čili paprika, krastavac, patlidžan, zelena salata, } \\
\text { češnjak, luk, kelj, koraba, poriluk, gljive, bundeva, rotkvica, tikvica i sve vrste tikvi, špinat, rajčica, repa, peršin, } \\
\text { blitva, artičoka, šparoge }\end{array}$ \\
\hline Voće & $\begin{array}{l}\text { Jabuka, marelica, banana, kupine, borovnice, trešnje, višnje, klementine, mandarine, brusnice, datulje, smokve, } \\
\text { grejp, grožđe, kivi, limun, dinja, naranča, limeta, mango, nektarina, breskva, kruška, ananas, šljiva, nar, maline, } \\
\text { jagode, lubenica }\end{array}$ \\
\hline Masnoće & $\begin{array}{l}\text { Masline i maslinovo ulje, avokado, kokos (ulje, ljuskice, brašno, mlijeko), orašasto voće (bademi, brazilski orah, } \\
\text { kesten, lješnjak, orah, pistacija), sjemenke (bučine, suncokretove, sezam) }\end{array}$ \\
\hline Napici & Voda, crna kava, biljni čajevi, limunada, vino \\
\hline Ostalo & Med, kakao prah, tamna čokolada (više od 70\% kakaa), začinsko bilje i začini u prahu \\
\hline
\end{tabular}

Tablica 3. Hrana koja ne ulazi u sastav paleolitičke prehrane

Table 3. Food that doesn't belong to the Paleolithic diet

\begin{tabular}{|c|c|}
\hline Skupina namirnica & Pripadajuća hrana \\
\hline Žitarice i krumpir & $\begin{array}{r}\text { Kruh, pšenica, ječam, zob, raž, heljda, riža, proso, kukuruz, krumpir, batat, amarant, bulgur, kvinoja, pir, tef i } \\
\text { proizvodi od navedenih žitarica }\end{array}$ \\
\hline Mahunarke & Grah, grašak, leća, slanutak, kikiriki, soja, sojino mlijeko, tofu, tempeh, miso \\
\hline Mliječni proizvodi & Mlijeko, sir, vrhnje, jogurt, kefir, puding, mliječni namaz, sladoled, maslac \\
\hline Zaslađivači & Bijeli i smeđi šećer, agavin sirup, javorov sirup, umjetna sladila, stevia \\
\hline Biljna ulja & $\begin{array}{r}\text { Suncokretovo ulje, sojino ulje, kanola ulje, margarin, palmino ulje, djelomično hidrogenizirana ulja i masti, trans- } \\
\text { masti }\end{array}$ \\
\hline Ostalo & Gazirana i negazirana bezalkoholna pića s dodanim šećerom, pivo, kolači, grickalice, slatkiši, fast food \\
\hline
\end{tabular}

Prije početka i nakon završetka intervencije ispitanicima je podijeljen upitnik o kvaliteti života Svjetske zdravstvene organizacije u svrhu procjene doživljaja kvalitete života, zdravlja i drugih područja života (The WHOQOL GROUP, 1998). Upitnik sadrži 26 pitanja i obuhvaća 4 domene, a sadržaj svake domene definiran je u tablici 4. Svako pitanje boduje se od 1 (najlošije) do 5 (najbolje) te se za svaku domenu zasebno transformiraju bodovi i prikazuju na skali 0-100, pri čemu više bodova znači bolju kvalitetu života. Prema rezultatima upitnika prije i nakon intervencije, dobivena je razlika u bodovima koja govori o tome je li se kvaliteta života unutar pojedine domene smanjila ili povećala nakon provedene intervencije. 
Tablica 4. Sadržaj pojedinih domena upitnika o kvaliteti života (The WHOQOL GROUP, 1998)

Table 4. Content of individual domains of the life quality questionnaire (The WHOQOL GROUP, 1998)

\begin{tabular}{|c|c|}
\hline Domena & Sadržaj koji se procjenjuje \\
\hline Tjelesno zdravlje & dnevne aktivnosti, ovisnost o medicinskoj njezi, razina energije, pokretnost, bol i nelagoda, spavanje, radne sposobnosti \\
\hline Psihičko zdravlje & $\begin{array}{r}\text { zadovoljstvo izgledom tijela, pozitivni i negativni osjećaji, samopoštovanje, duhovnost i osobna vjerovanja, razmišljanje } \\
\text { pamćenje, koncentracija }\end{array}$ \\
\hline Društveni odnosi & zadovoljstvo osobnim odnosima, seksualnim životom i društvenom podrškom \\
\hline Okolina & $\begin{array}{r}\text { zadovoljstvo financijskim sredstvima, kvaliteta zdravstvene i socijalne njege, vlastito kućanstvo, mogućnost rekreacije, } \\
\text { učenja i razvoja vještina, zagađenje okoliša, buka, promet, klima }\end{array}$ \\
\hline
\end{tabular}

Nakon završetka istraživanja ispitanici su ispunili upitnik o prihvatljivosti paleolitičke prehrane (skraćeni oblik upitnika iz studije Genoni i sur., 2016) koji prikazuje njihov doživljaj ovakvog načina prehrane.

Tjelesna masa izmjerena je svim ispitanicima uz pomoć analogne osobne vage, u odjeći bez obuće, neovisno o stupnju popunjenosti probavnog sustava, a mjerenje tjelesne visine obavljeno je mjernom trakom uz pomoć letvice (postavljene iznad glave), bez obuće, s položajem glave u Frankfurt horizontalnoj ravnini. Iz dobivenih vrijednosti izračunat je indeks tjelesne mase.

Biokemijske parametre ispitanici su odredili biokemijskom pretragom na koju ih je uputio osobni liječnik. Prije početka intervencije prikupljeni su nalazi zadnje učinjenih vrijednosti glikemijske regulacije koje su ispitanici napravili (između jednog tjedna i 15 mjeseci unatrag), a četvero ispitanika pretragu je napravilo tijekom ožujka, nakon početka intervencije. Na kraju istraživanja ispitanici su ponovno napravili biokemijski nalaz (većina ispitanika u roku od mjesec dana) kako bi se usporedili biokemijski parametri prije i nakon intervencije. Relevantan parametar glikemijske regulacije bio je prvenstveno $\mathrm{HbAlc}$ te je podatak o vrijednosti istog prikupljen za sve ispitanike i prije i nakon intervencije. Tijekom cijelog perioda trajanja intervencije, jednom tjedno (na isti dan i u isto vrijeme) održavana su edukativna predavanja, na kojima su ispitanici dobivali detaljne inforamcije o paleolitičkoj prehrani, praktične savjete, kao i odgovore na pitanja. Održavane su i edukativne radionice, organizirane kao interaktivno dijeljenje iskustava ili kao kviz, te kulinarske radionice, tijekom kojih je ispitanicima prezentirana priprema pojedinih jela i obroka u skladu s pravilima paleolitičke prehrane.

Statistička obrada podataka provedena je u programu Microsoft Office Excel 2016 (Microsoft Corp.) u svrhu izrade grafičkih prikaza, izračunavanja srednjih vrijednosti, standardnih devijacija, pouzdanih intervala, p-vrijednosti $\chi 2$-testova i ostalih potrebnih računskih operacija.

\section{Rezultati i rasprava}

Podaci u tablici 5. prikazuju promjene promatranih parametara prije i nakon intervencije prema kojima je, iako minimalno, vidljivo smanjenje tjelesne mase, indeksa tjelesne mase i postotka $\mathrm{HbA} 1 \mathrm{c}$ nakon 12 tjedana trajanja intervencije.

Tablica 5. Podaci o ispitanicima prije i nakon intervencije $(n=8)$

Table 5. Participants'data before and after intervention ( $n=8)$

\begin{tabular}{|c|c|c|c|c|c|c|c|c|}
\hline \multirow[b]{2}{*}{ Parametar } & \multicolumn{4}{|c|}{ Prije intervencije } & \multicolumn{4}{|c|}{ Nakon intervencije } \\
\hline & $\begin{array}{l}\text { Srednja } \\
\text { vrijednost } \\
\quad \pm \mathrm{SD}\end{array}$ & $\begin{array}{c}\text { 95\% pouzdani } \\
\text { interval za } \\
\text { očekivanje }\end{array}$ & $\begin{array}{l}\text { 99\% pouzdani } \\
\text { interval za } \\
\text { očekivanje }\end{array}$ & $\begin{array}{c}\text { p-vrijednost } \\
\chi 2 \text {-testa } \\
\text { pretpostavke } \\
\text { o normalnoj } \\
\text { distribuciji } \\
\text { uzorka }\end{array}$ & $\begin{array}{l}\text { Srednja } \\
\text { vrijednost } \\
\quad \pm \mathrm{SD}\end{array}$ & $\begin{array}{c}95 \% \\
\text { pouzdani } \\
\text { interval za } \\
\text { očekivanje }\end{array}$ & $\begin{array}{c}99 \% \\
\text { pouzdani } \\
\text { interval za } \\
\text { očekivanje }\end{array}$ & $\begin{array}{c}\text { p-vrijednost } \\
\chi 2 \text {-testa } \\
\text { pretpostavke } \\
\text { o normalnoj } \\
\text { distribuciji } \\
\text { uzorka }\end{array}$ \\
\hline Dob (godine) & $70,1 \pm 4,9$ & $\begin{array}{c}665,994 ; \\
74,255]\end{array}$ & $\begin{array}{c}{[64,012 ;} \\
76,238]\end{array}$ & 0,846 & $=$ & $=$ & $=$ & $=$ \\
\hline $\begin{array}{c}\text { Tjelesna visina } \\
(\mathrm{m})\end{array}$ & $1,61 \pm 0,11$ & {$[1,519 ; 1,703]$} & {$[1,475 ; 1,747]$} & 0,797 & $=$ & $=$ & $=$ & $=$ \\
\hline $\begin{array}{c}\text { Tjelesna masa } \\
(\mathrm{kg})\end{array}$ & $80 \pm 15,3$ & $\begin{array}{c}{[67,221 ;} \\
92,779]\end{array}$ & $\begin{array}{c}61,088 ; \\
98,911]\end{array}$ & 0,882 & $78,9 \pm 15,7$ & $\begin{array}{c}665,752 ; \\
91,998]\end{array}$ & $\begin{array}{c}59,453 \\
98,297]\end{array}$ & 0,812 \\
\hline $\begin{array}{c}\text { Indeks tjelesne } \\
\text { mase }\left(\mathrm{kg} / \mathrm{m}^{2}\right)\end{array}$ & $30,7 \pm 5,0$ & $\begin{array}{c}{[26,561 ;} \\
34,889]\end{array}$ & $\begin{array}{c}24,563 ; \\
35,705]\end{array}$ & 0,154 & $30,2 \pm 4,2$ & $\begin{array}{c}{[26,739 ;} \\
33,711]\end{array}$ & $\begin{array}{c}{[25,067 ;} \\
35,383]\end{array}$ & 0,103 \\
\hline HbA1c (\%) & $6,3 \pm 0,5$ & {$[5,926 ; 6,724]$} & {$[5,734 ; 6,916]$} & 0,759 & $6,2 \pm 0,5$ & $\begin{array}{c}{[5,744 ;} \\
6,656]\end{array}$ & $\begin{array}{c}{[5,526 ;} \\
6,874]\end{array}$ & 0,134 \\
\hline
\end{tabular}

$\mathrm{Na}$ razini skupine, smanjenje srednje vrijednosti tjelesne mase iznosilo je $1,1 \mathrm{~kg}(1,4 \%)$, a smanjenje indeksa tjelesne mase $0,5 \mathrm{~kg} / \mathrm{m}^{2}(1,6 \%)$ Smanjenje tjelesne mase, kao i indeksa tjelesne mase, evidentirano je u većini ostalih istraživanja istog trajanja u kojima se promatrao utjecaj paleolitičke prehrane i u kojima su navedena smanjenja bila višestruko veća nego u ovom istraživanju (Lindeberg i sur, 2007; Otten i sur., 2017). 
Kao uzroci smanjenja tjelesne mase navode se smanjenje energetskog unosa, povećan unos proteina te visok unos voća i povrća koje sadrži puno vode, a oba ova faktora doprinose većem osjećaju sitosti i nižoj energetskoj gustoći (Jönsson i sur., 2009). Smatra se da smanjenje tjelesne mase između 5-10 \% kod osoba s dijabetesom tipa 2 i inzulinskom rezistencijom poboljšava glikemiju za 10-20 \% (Petrović, 2011). Prema tome, ne može se zaključiti da je smanjenje tjelesne mase u ovom istraživanju bilo značajno, kao ni da bi moglo imati značajan utjecaj na glikemiju.

Iz tablice 5. vidljivo je kako se srednja vrijednost postotka $\mathrm{HbAlc}$ smanjila za $0,1 \%$. Takva redukcija značajno je manja od rezultata postignutih u sličnim istraživanjima, gdje iznosi i do $0,9 \%$, a kao objašnjenje takve redukcije spominje se povećanje inzulinske osjetljivosti tj. učinkovitije iskorištavanje inzulina (Otten i sur., 2017; Jönsson i sur. 2009). Ustanovljeno je da redukcija HbA1c za samo 0,2 $\%$ smanjuje mortalitet za $10 \%$ (Sherwani i sur., 2016), dok nešto veća redukcija $\mathrm{HbA} 1 \mathrm{c}$ u iznosu od $1 \%$ smanjuje prosječnu razinu glukoze u krvi za oko 1,6 mmol/L (Radin, 2014) te također smanjuje rizik od mikrovaskularnih komplikacija za 37 \% (Otten i sur., 2017). Hrvatske smjernice za liječenje šećerne bolesti tipa 2 definirale su ciljne vrijednosti HbA1c kao vrijednost $<6,5 \%$ (Kokić i sur., 2011). Prema tome se može zaključiti kako su ispitanici i prije i nakon intervencije prema prosječnoj vrijednosti imali zadovoljavajuću vrijednost postotka $\mathrm{HbA1c}$, što je umanjilo vjerojatnost postizanja dodatnog učinka.

Slika 1. prikazuje rezultate upitnika o kvaliteti života izražene kao promjenu kvalitete života prije i nakon intervencije prema pojedinim domenama, prikazane Box and whisker dijagramom. Kod svake domene križić označava srednju vrijednost prema kojoj se može zaključiti kako se kvaliteta tjelesnog $(0,1 \%)$ i psihičkog zdravlja $(3,1 \%)$ nije značajno promijenila, dok se kvaliteta društvenih odnosa povećala za $10,9 \%$, a kvaliteta okoline za 6,6 \%. Ovakva vrsta upitnika do sada se nije koristila $\mathrm{u}$ istraživanjima s paleolitičkom prehranom, no postoji mogućnost da je poboljšanje kvalitete društvenih odnosa povezano sa društvenim okupljanjima na edukativnim radionicama u sklopu ovog istraživanja, gdje je postojala međusobna interakcija među ispitanicima. Poboljšanje kvalitete okoline vjerojatno nije rezultat utjecaja ovog istraživanja na ispitanike, već promjena njihove percepcije prema okolini.

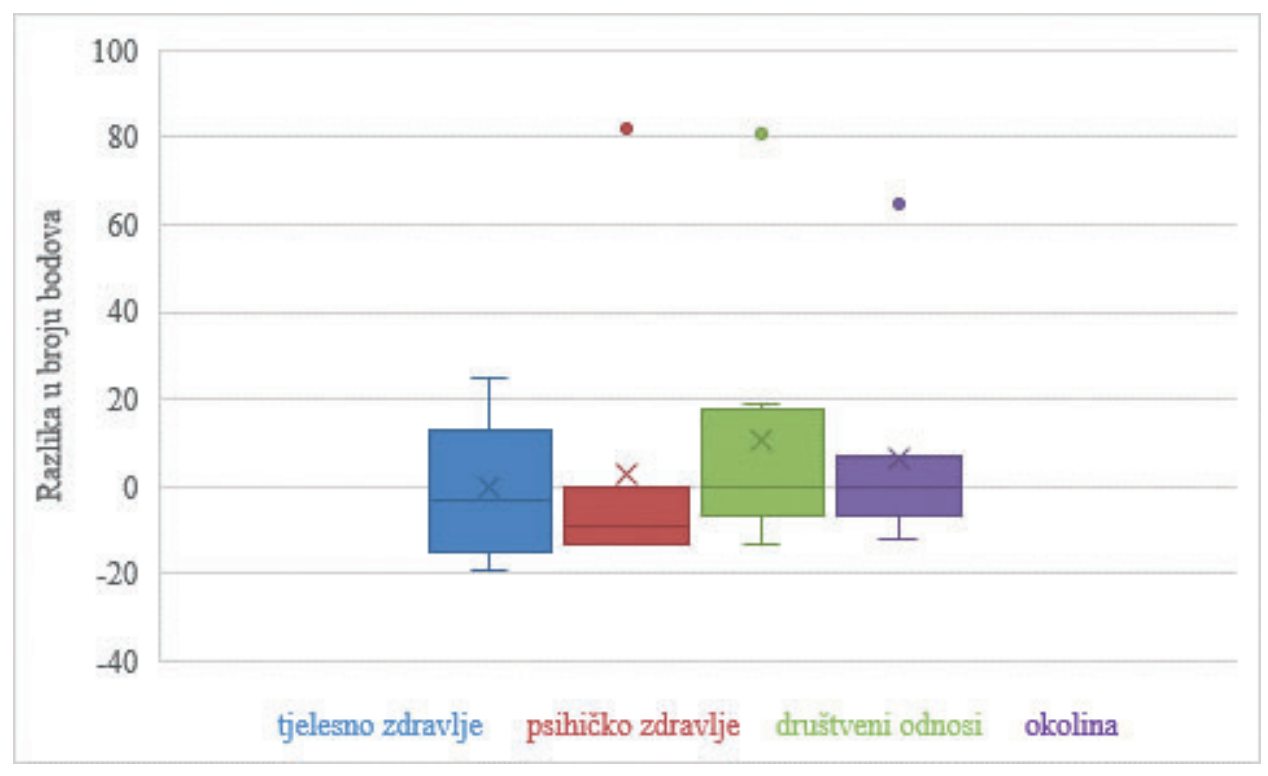

Slika 1. Razlika u kvaliteti života prije i nakon intervencije

Figure 1. Difference in quality of life before and after intervention

Upitnik o prihvatljivosti paleolitičke prehrane poslužio je u svrhu procjene osobnog doživljaja paleolitičke prehrane od strane ispitanika. Popis pitanja s raspodjelom pripadajućih odgovora prikazan je na slici 2. Odgovori na većinu pitanja pokazuju zadovoljavajuću prihvatljivost ovakvog načina prehrane s obzirom na percepciju zdravstvenog utjecaja, lakoću pridržavanja, stupanj sitosti, ukusnost, smanjenu potrebu za slatkom hranom, lakoću nabave namirnica te s obzirom na percepciju općeg zdravlja i blagostanja. Prehrana se pokazala neprihvatljivom jedino u pogledu visokog iznosa troškova nabave namirnica.

U usporedbi s istraživanjem Genoni i sur. iz 2016. gdje se koristio sličan upitnik, kod ovog istraživanja bio je veći postotak pozitivnih odgovora što znači da se prihvatljivost paleolitičke prehrane u ovom istraživanju pokazala većom nego u spomenutom istraživanju. Jedina iznimka je pitanje o utjecaju na sitost, na koje je manji broj ispitanika nego u istraživanju Genoni i sur., 2016. definirao stupanj sitosti nakon obroka kao "vrlo sit" ili "sit". $\mathrm{Na}$ isto pitanje jedan ispitanik, vjerojatno nenamjerno, nije dao odgovor, dok su na 9. pitanje dva ispitanika dala dva odgovora (umjesto jednog, pa je ukupno 10 odgovora) zbog nedovoljnog razumijevanja zadatka. Mogući uzrok visokoj zastupljenosti pozitivnih odgovora je redovita edukacija ispitanika, povezana s razmjenom praktičnih savjeta što je imalo svrhu povećati informiranost i olakšati pridržavanje novog obrasca prehrane. 
Pitanja upitnika

Broj pojedinih odgovora (jedan kvadrat označava jedan odgovor) *iznimka je 9. pitanje koje umjesto 8 sadrži 10 odgovora

1. Kako biste procijenili utjecaj paleolitičke prehrane na zdravlje?

2. Smatrate li da paleolitička prehrana odgovara vašim vjerovanjima o zdravoj prehrani?

3. Kako biste procijenili lakoću/težinu prilagodbe ovakvom načinu prehrane?

4. Kako biste ocijenili stupanj sitosti nakon obroka?

5. Kako biste ocijenili ukusnost paleolitičke prehrane u usporedbi s uobičajenom prehranom?

6. Osjećate li smanjenu potrebu za slatkim nakon 3 mjeseca paleolitičke prehrane?

7. Kako biste ocijenili osjećaj općeg zdravlja i blagostanja nakon promjene prehrane?

8. Koliko lako vam je bilo kupovati hranu koja se smatra dozvoljenom?

*9. Kako biste procijenili paleolitičku prehranu prema iznosu troškova kupnje namirnica?

10. Biste li preporučili ovakav način prehrane obitelji i prijateljima?

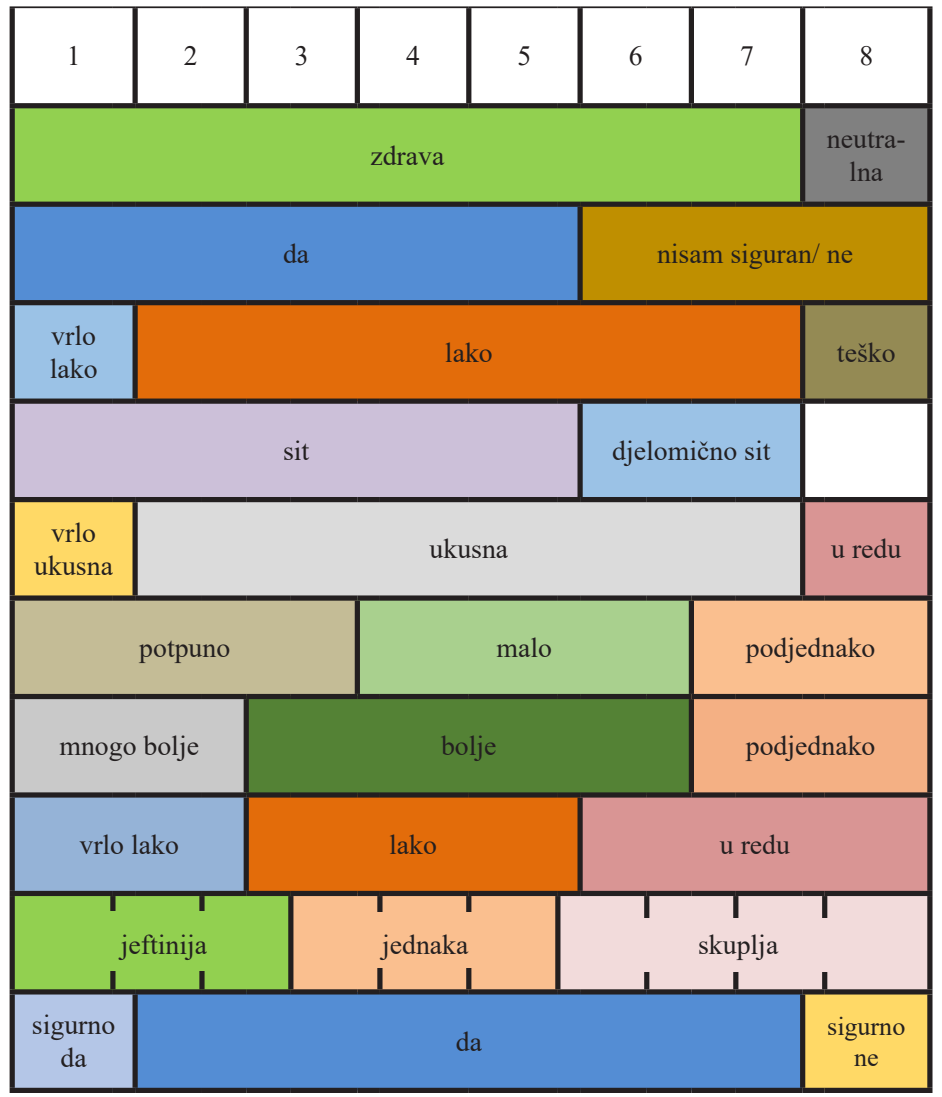

Slika 2. Rezultati upitnika o prihvatljivosti paleolitičke prehrane

Figure 2. Acceptability of the Paleolithic diet

Iako su rezultati ovog istraživanja pokazali vrlo malu promjenu promatranih parametara, ostala dosadašnja istraživanja sa značajnijim rezultatima sugeriraju velik potencijal paleolitičke prehrane uz naglašenu potrebu za dodatnim i opširnijim istraživanjima (Lindeberg i sur., 2007; Jönsson i sur. 2009; Otten i sur., 2017). Ograničenje ovog istraživanja svakako je nedostatak kontrolne skupine te mali broj ispitanika pri čemu je nekoliko pojedinaca ostvarilo značajne rezultate, no na razini skupine nisu vidljive značajne promjene u pojedinim parametrima. Uzrok tome mogao bi biti nejednak i neadekvatan stupanj pridržavanja pravila paleolitičke prehrane među ispitanicima iz razloga kao što je financijski trošak, manjak motivacije ili teškoće u planiranju i pripremi obroka.

\section{Zaključci}

Kod osoba s dijabetesom tipa 2, u ovom malom uzorku od 8 ispitanika, pridržavanje paleolitičke prehrane u trajanju od 12 tjedana rezultiralo je vrlo malim promjenama u tjelesnoj masi i postotku HbA1c, stoga se takva poboljšanja ne mogu smatrati značajnima. Iako se na razini skupine nije promijenilo zadovoljstvo kvalitetom tjelesnog i psihičkog zdravlja, poboljšala se kvaliteta društvenih odnosa i okoline. Upitnikom o prihvatljivosti paleolitičke prehrane procijenjeno je kako je ispitanicima ovakav način prehrane prihvatljiv, a kao jedini faktor neprihvatljivosti pokazao se financijski trošak nabave namirnica. Ovi preliminarni rezultati s naznakama koristit će se kao temelj narednih aktivnosti na istu temu kroz udruge oboljelih od dijabetesa tipa 2.

\section{Literatura}

American Diabetes Association (ADA) (2008) Nutrition Recommendations and Interventions for Diabetes. A position statement of the American Diabetes Association. Diabetes Care, 31 (1) 61-78.

Boers I., Muskiet F. A. J., Berkelaar E., Schut E., Penders R., Hoenderdos K., Wichers H. J., Jong M. C. (2014) Favourable effects of consuming a Palaeolithictype diet on characteristics of the metabolic syndrome: a randomized controlled pilot-study. Lipids in Health and Disease, 13 1-13.

Cordain L., Eaton S. B., Sebastian A., Mann N., Lindeberg S., Watkins B. A., O'Keefe J. H., Brand-Miller J. (2005) Origins and evolution of the Western diet: health implications for the 21st century. The American Journal of Clinical Nutrition, 81 341-354.

Genoni A., Lo J., Lyons-Wall P., Devine A. (2016) Compliance, palatability and feasibility of Paleolithic and Australian Guide to Healthy Eating diets in healthy women: a 4-week dietary intervention. Nutrients, doi: 10.3390/nu8080481

Ghaedi E., Mohammadi M., Mohammadi H., Ramezani-Jolfaie N., Malekzadeh J., Hosseinzadeh M., Salehi-Abargouei A. (2019) Effects of a 
Paleolithic diet on cardiovascular disease risk factors: a systematic review and meta-analysis of randomized controlled trials. Advances in Nutrition, 10 (4) 634-646.

Gregg E. W., Cheng Y. J., Cowie C., Garfield S., Geiss L., Barker L. (2012) Trends in death rates among U.S. adults with and without diabetes between 1997 and 2006. Diabetes Care, 35 1252-1257.

Hrvatski zavod za javno zdravstvo (HZJZ) (2019) Epidemiološki podaci o šećernoj bolesti. Dostupno na: https://www.hzjz.hr/sluzba-epidemiologijaprevencija-nezaraznih-bolesti/epidemioloski-podaci-o-secernoj-bolesti/. Pristupljeno: 20.02.2020.

International Diabetes Federation (IDF) (2019) Diabetes Atlas reports 463 million with diabetes. Dostupno na: https://idf.org/news/169:diabetes-atlasreports-463-million-with-diabetes.html. Pristupljeno: 20.02.2020.

Jew S., AbuMweis S. S., Jones P. J. H. (2009) Evolution of the human diet: linking our ancestral diet to modern functional foods as a means of chronic disease prevention. Journal of Medicinal Food, 12 925-934.

Jönsson T., Granfeldt Y., Ahrén B., Branell U. C., Pålsson G., Hansson A., Söderström M., Lindeberg S. (2009) Beneficial effects of a Paleolithic diet on cardiovascular risk factors in type 2 diabetes: a randomized cross-over pilot study. Cardiovascular Diabetology, 835.

Jönsson T., Granfeldt Y., Erlanson-Albertsson C., Ahrén B., Lindeberg S. (2010) A paleolithic diet is more satiating per calorie than a mediterraneanlike diet in individuals with ischemic heart disease. Nutrition \& Metabolism, 785.

Kokić S., Prašek M., Pavlić Renar I., Rahelić D., Pavić E., Jandrić Balen M., Radman M., Duvnjak L., Jurišić-Eržen D., Božikov V., Matić T., ZjačićRotkvić V., Crnčević-Orlić Ž., Krnić M., Metelko Ž. (2011) Hrvatske smjernice za liječenje šećerne bolesti tipa 2. Medix, 96 8-34.

Kopp W. (2006) The atherogenic potential of dietary carbohydrate. Preventive Medicine, 42 336-342.

Lieberman L. S. (2003) Dietary, evolutionary, and modernizing influences on the prevalence of type 2 diabetes. Annual Review of Nutrition, 23 345-377.

Lindeberg S., Jönsson T., Granfeldt Y., Borgstrand E., Soffman J., Sjöström K., Ahrén B. (2007) A Palaeolithic diet improves glucose tolerance more than a Mediterranean-like diet in individuals with ischaemic heart disease. Diabetologia, 50 1795-1807.

Lindeberg S. (2012) Paleolithic diets as a model for prevention and treatment of Western disease. American Journal of Human Biology, 24 110-115. Manheimer E. W., van Zuuren E. J., Fedorowitcz Z., Pijl H. (2015) Paleolithic nutrition for metabolic syndrome: systematic review and meta-analysis. The American Journal of Clinical Nutrition, 102 922-932.

Masharani U., Sherchan P., Schloetter M., Stratford S., Xiao A., Sebastian A., Kennedy M. N., Frassetto L. (2015) Metabolic and physiologic effects from consuming a hunter-gatherer (Paleolithic)-type diet in type 2 diabetes. European Journal of Nutrition, 69 944-948.

Moosheer S. M., Waldschütz W., Itariu B. K., Brath H., Stulnig T. M. (2014) A protein-enriched low glycemic index diet with omega-3 polyunsaturated fatty acid supplementation exerts beneficial effects on metabolic control in type 2 diabetes. Primary Care Diabetes, 8 308-314.

Otten J., Stomby A., Waling M., Isaksson A., Tellström A., Lundin-Olsson L., Brage S., Ryberg M., Svensson M., Olsson T. (2017) Benefits of a Paleolithic diet with and without supervised exercise on fat mass, insulin sensitivity, and glycemic control: a randomized controlled trial in individuals with type 2 diabetes. Diabetes/Metabolism Research and Reviews, $331-11$.

Petrović G. (2011) Akcijski plan za prevenciju i smanjenje prekomjerne tjelesne težine. Hrvatski časopis za javno zdravstvo, 7 1-3.

Radin M. S. (2014) Pitfalls in hemoglobin A1c measurement: when results may be misleading. Journal of General Internal Medicine, 29 388-394.

Sherwani S. I., Khan H. A., Ekhzaimy A., Masood A., Sakharkar M. K. (2016) Significance of HbA1c test in diagnosis and prognosis of diabetic patients. Biomarker Insights, 11 95-104.

The WHOQOL GROUP. (1998) Development of the World Health Organization WHOQOL-BREF Quality of Life Assessment. Psychological Medicine, 1(28) 551-558. 